\title{
Time- and age-related effects of experimentally simulated nitrogen deposition on the functioning of montane heathland ecosystems
}

\author{
Javier Calvo-Fernández ${ }^{\mathrm{a}, *}$, Ángela Taboada ${ }^{\mathrm{a}}$, Andreas Fichtner ${ }^{\mathrm{b}}$, Werner Härdtle ${ }^{\mathrm{b}}$, Leonor Calvo ${ }^{\mathrm{a}}$, Elena Marcos ${ }^{\mathrm{a}}$ \\ a Area of Ecology, Faculty of Biological and Environmental Sciences \& Institute of Environmental Research (IMA), University of León, 24071 León, Spain \\ ${ }^{\mathrm{b}}$ Institute of Ecology, Leuphana University of Lüneburg, Scharnhorststrasse 1, 21335 Lüneburg, Germany
}

\section{A R T I C L E I N F O}

\section{Article history:}

Received 12 May 2017

Received in revised form 23 August 2017

Accepted 24 August 2017

Available online $\mathrm{xxx}$

Editor: Elena PAOLETTI

Keywords:

Air pollution

Calluna vulgaris heathland

Plant-litter-soil nutrient relationship

Extracellular enzymatic activity

Soil microbial biomass

Ericoid mycorrhizal colonization

\begin{abstract}
A B S T R A C T
Ecosystems adapted to low nitrogen $(\mathrm{N})$ conditions such as Calluna-heathlands are especially sensitive to enhanced atmospheric $\mathrm{N}$ deposition that affects many aspects of ecosystem functioning like nutrient cycling, soil properties and plant-microbial-enzyme relationships. We investigated the effects of five levels of experimentally-simulated $\mathrm{N}$ deposition rates (i.e., $\mathrm{N}$ fertilization treatments: $0,10,20$ and $50 \mathrm{~kg} \mathrm{~N}^{-1} \mathrm{yr}^{-1}$ for 3 years, and $56 \mathrm{~kg} \mathrm{~N} \mathrm{ha}^{-1} \mathrm{yr}^{-1}$ for 10 years) on: plant, litter, microbial biomass and soil nutrient contents, soil extracellular enzymatic activities, and plant root ericoid mycorrhizal colonization. The study was conducted in marginal montane Calluna-heathlands at different developmental stages resulting from management (young/building-phase and mature-phase). Our findings revealed that many soil properties did not show a statistically significant response to the experimental addition of $\mathrm{N}$, including: total $\mathrm{N}$, organic carbon $(\mathrm{C}), \mathrm{C}: \mathrm{N}$ ratio, extractable $\mathrm{N}^{-\mathrm{NO}_{3}}{ }_{3}$, available phosphorus $(\mathrm{P})$, urease and $\beta$-glucosidase enzyme activities, and microbial biomass $\mathrm{C}$ and $\mathrm{N}$. Our results also evidenced a considerable positive impact of chronic (10-year) high-N loading on soil extractable $\mathrm{N}_{-} \mathrm{NH}_{4}^{+}$, acid phosphatase enzyme activity, Calluna root mycorrhizal colonization by ericoid fungi, Calluna shoot $\mathrm{N}$ and $\mathrm{P}$ contents, and litter $\mathrm{N}$ content and N:P ratio. The age of heathland vegetation influenced the effects of $\mathrm{N}$ addition on ericoid mycorrhizal colonization, resulting in higher colonized roots in young heathlands at the control, low and medium N-input rates; and in mature ones at the high and chronically high $\mathrm{N}$ rates. Also, young heathlands exhibited greater soil extractable $\mathrm{N}_{-} \mathrm{NO}_{3}{ }^{-}$, available $\mathrm{P}$, microbial biomass N, Calluna shoot $\mathrm{N}$ and $\mathrm{P}$ contents, and litter $\mathrm{N}$ content, compared to mature ones. Our results highlighted that accounting for the $\mathrm{N}$-input load and duration, as well as the developmental stage of the vegetation, is important for assessing the effects of added N, particularly at the heathlands' southern distribution limit.
\end{abstract}

\section{Introduction}

The increase in human-induced atmospheric reactive nitrogen $(\mathrm{N})$ in the last century has resulted in a dramatically increase in $\mathrm{N}$ deposition rates (Calvo-Fernández et al., 2017), which are expected to rise in future decades at a global scale (Galloway et al., 2004), with slight differences between developing regions and industrialized ones (Vet et al., 2014). Airborne $\mathrm{N}$ loading has been identified as one of the most important drivers of biodiversity loss at a global scale (Sala et al., 2000), which in turn is expected to have negative consequences for multiple ecosystem functions. There exists compelling evidence of $\mathrm{N}$-driven damage to ecosystems even at low deposition rates (Bähring et al., 2017; Phoenix et al., 2012). Moreover, chronic $\mathrm{N}$ loading has severe impacts on many ecosystem functions when the critical $\mathrm{N}$ threshold is exceeded (Gao et al., 2014). These harmful effects are caused by ecosystem eutrophication and soil acidification processes (Bobbink et al., 2010; Stevens et al., 2011; Zhu et al.,

\footnotetext{
* Corresponding author.

Email address: jcalf@unileon.es (J. Calvo-Fernández)
}

2015), altering the biogeochemical cycles of N, carbon (C) and phosphorus (P) (Erisman et al., 2011).

Ecosystems adapted to low levels of nutrient availability, such as heathlands dominated by the dwarf shrub Calluna vulgaris (L.) Hull (henceforth referred to as Calluna), are particularly sensitive to airborne N deposition (Cuesta et al., 2008; Fagúndez, 2013; Jones and Power, 2012; Meyer-Grünefeldt et al., 2016; Southon et al., 2012). Both field-scale surveys and N-manipulation experiments testing the effects of a variety of $\mathrm{N}$-loading rates over different temporal scales have evidenced substantial N-driven changes in the composition, diversity and functioning of nutrient-poor Calluna-heathlands (e.g., Calvo et al., 2005, 2007; Friedrich et al., 2011; Power et al., 2006; Southon et al., 2013), threatening their persistence across Europe (Fagúndez, 2013). Moreover, several studies have evaluated the cumulative effects of $\mathrm{N}$ in heathland ecosystems (Johnson et al., 1998; Phoenix et al., 2012; Southon et al., 2012; among others), since chronic $\mathrm{N}$ loading is expected to aggravate the impact of $\mathrm{N}$ even at low input rates (Phoenix et al., 2012; Power et al., 2006).

Increased $\mathrm{N}$ inputs alter a multitude of heathland characteristics such as soil and litter properties (e.g., nutrient availability, enzyme activities or microbial biomass) or plant traits [e.g., growth, flower- 
ing, tissue and litter chemistry or plant susceptibility to biotic (e.g., pathogen or pests) and abiotic (e.g., frost or drought) stressors] (Bähring et al., 2017; Jones and Power, 2012; Marcos et al., 2003; Meyer-Grünefeldt et al., 2016; Southon et al., 2013; Taboada et al., 2016). Elevated $\mathrm{N}$ inputs stimulate $\mathrm{N}$ mineralization rates (Phoenix et al., 2012), resulting in increased soil extractable $\mathrm{N}_{-} \mathrm{NH}_{4}{ }^{+}$and $\mathrm{N}-\mathrm{NO}_{3}{ }^{-}$ (Boot et al., 2016; Song et al., 2017; Southon et al., 2013). This enhanced soil $\mathrm{N}$ availability may cause either an increase (Du et al., 2014; Haugwitz et al., 2011) or decrease (Ajwa et al., 1999; Boot et al., 2016) in the nutrient contents of the soil microbial biomass, altering the cycles of soil $\mathrm{C}$ and $\mathrm{N}$ (Contosta et al., 2015; Ramírez et al., 2012; Zhu et al., 2015), and the ericoid mycorrhizal (ERM) fungal community associated with Calluna in nutrient-poor environments (Caporn et al., 1995; Yesmin et al., 1996). Since soil microorganisms are considered the primary sources of soil enzymes, and these are involved in nutrient metabolism and decomposition processes (Fatemi et al., 2016; Ramírez et al., 2012; Sinsabaugh and Follstad, 2012; Song et al., 2017; Zhu et al., 2015), an increase in $\mathrm{N}$ inputs is expected to alter soil enzymatic activities such as acid phosphatase ( $\mathrm{P}$ cycle), urease $(\mathrm{N}$ cycle) and $\beta$-glucosidase (C cycle) (Ajwa et al., 1999; Jian et al., 2016; Ochoa-Hueso et al., 2011, 2014). These variations very likely affect the storage, turnover and uptake of soil nutrients (Cenini et al., 2016; Jones and Power, 2012). As a result, excess $\mathrm{N}$ accumulation in heathland ecosystems promotes enhanced rates of nutrient uptake by $\mathrm{Cal}$ luna plants and subsequent increases in foliar tissue $\mathrm{N}$ and $\mathrm{P}$ contents (Calvo et al., 2007; Jones and Power, 2012; Pilkington et al., 2005b; Rowe et al., 2008; von Oheimb et al., 2010), as well as increases in litter $\mathrm{N}$ and $\mathrm{P}$ contents (Pilkington et al., 2005b).

Age-related differences in Calluna nutrient uptake and growth rate are expected to influence the impacts of $\mathrm{N}$ deposition on heathlands (Jones and Power, 2015; Meyer-Grünefeldt et al., 2015), but till now only a limited number of studies have assessed these effects (i.e., Britton et al., 2008; Jones and Power, 2015). European heathlands have traditionally been managed to create pastures for breeding livestock and their nutrient poor status has been preserved through practices as mowing, sod cutting and prescribed burning (Fagúndez, 2013; Härdtle et al., 2006, 2009), resulting in the periodic rejuvenation of heathland vegetation (Gimingham, 1972; Henning et al., 2017). In recent decades, however, land use abandonment has led to heathland management cessation and to Calluna plants reaching the mature or degenerate phase of development (sensu Gimingham, 1972; Calvo et al., 2007; Henning et al., 2017). As time progresses since the last management (e.g., prescribed burning, mowing, sod-cutting, and grazing), ageing heathland ecosystems accumulate $\mathrm{N}$ in soils and in the vegetation biomass (Härdtle et al., 2009; Jones and Power, 2015). Therefore, specific measures to compensate for atmospheric $\mathrm{N}$ deposition are required to remove the excess of $\mathrm{N}$ stored in the ecosystem, and, thus to keep a low-N status (Calvo et al., 2005; Härdtle et al., 2006, 2009; Marcos et al., 2009).

In contrast to north-western (e.g., Phoenix et al., 2012; Southon et al., 2012) and central European (e.g., Bähring et al., 2017; de Vries et al., 2009; Friedrich et al., 2011) Calluna-heathlands, to date, only one study has been developed on the time-scale and age-related effects of enhanced $\mathrm{N}$ deposition in montane Calluna-heathlands located at the southern-most limit of their distribution range (Cantabrian Mountains, NW Spain) (i.e., plant-herbivore-predator relationships: Taboada et al., 2016). This is despite these marginal southern Calluna-heathlands having been found to respond differently to global change drivers (such as $\mathrm{N}$ deposition) as compared to central European ones (Meyer-Grünefeldt et al., 2016). In this study, we evaluated the effects of different levels of experimentally simulated $\mathrm{N}$ deposi- tion on the functioning of marginal montane Calluna-heathlands, mediated by the age of heathland vegetation resulting from management activities (prescribed burning), with particular attention being paid to the cumulative impact of $\mathrm{N}$ loading throughout time. Specifically, we assessed the effects of five levels of $\mathrm{N}$ fertilization rates $(0,10,20$ and $50 \mathrm{~kg} \mathrm{~N} \mathrm{ha}^{-1} \mathrm{yr}^{-1}$ for 3 years, and $56 \mathrm{~kg} \mathrm{~N} \mathrm{ha}^{-1} \mathrm{yr}^{-1}$ for 10 years) on: (1) soil chemical properties, (2) soil extracellular enzymatic activities, (3) soil microbial biomass $\mathrm{C}$ and $\mathrm{N}$, (4) plant mycorrhizal colonization, (5) plant nutrient uptake and (6) litter chemistry. To our knowledge, this is the first study that evaluates the overall impact of cumulative $\mathrm{N}$ loading on plant-soil-microbial-enzyme relationships in both young and mature developmental stages of European heathlands.

We hypothesize that an increase in $\mathrm{N}$ loading will result in: (1) a subsequent increase in plant-litter-soil $\mathrm{N}$ and $\mathrm{P}$ contents due to higher nutrient accumulation and immobilization, as well as an increase in plant and litter N:P ratios (Britton et al., 2008; Southon et al., 2013; von Oheimb et al., 2010); (2) faster rates of extracellular enzymatic activities to supply higher plant and microbial nutrient demands (Ochoa-Hueso et al., 2011, 2014); (3) a rise in soil microbial biomass C and N (Haugwitz et al., 2011; Power et al., 2006), and (4) variations in the extent of root mycorrhizal colonization related to plant nutrient demands (Caporn et al., 1995; Rowe et al., 2008). We also hypothesize that chronic (10-year) $\mathrm{N}$ inputs will have a greater impact compared to short-term (3-year) N loading (Phoenix et al., 2012). Furthermore, we expect that higher plant and soil microbial biomass in mature heathlands relative to young ones will have comparatively greater nutrient demands resulting from $\mathrm{N}$ fertilization (due to nutrient stoichiometry) (Wendling et al., 2016), which, in turn, should be mirrored by lower soil nutrient contents (Ajwa et al., 1999).

\section{Material and methods}

\subsection{Study area}

The study area is located on the southern slope of the Cantabrian mountain range (NW Spain). We selected three representative and homogeneous Calluna-heathland sites situated at least $3 \mathrm{~km}$ apart: Riopinos I (1660 $\mathrm{m}$ a.s.1., $\left.43^{\circ} 02^{\prime} \mathrm{N}, 5^{\circ} 24^{\prime} \mathrm{W}, 24 \mathrm{ha}\right)$ is a discontinuous northern-exposed heathland on a steep slope; Riopinos II (1560 m a.s.l., $\left.43^{\circ} 02^{\prime} \mathrm{N}, 5^{\circ} 26^{\prime} \mathrm{W}, 18 \mathrm{ha}\right)$ is a wind-exposed heathland in a north-facing area with a low slope; San Isidro $\left(1620 \mathrm{~m}\right.$ a.s. $1 ., 43^{\circ} 03^{\prime} \mathrm{N}$, $\left.5^{\circ} 21^{\prime} \mathrm{W}, 35 \mathrm{ha}\right)$ is a flat and continuous heathland facing north and exposed to winds. The climate is Eurosiberian with a mean annual temperature of $5.5^{\circ} \mathrm{C}$. Mean annual precipitation is $1645 \mathrm{~mm}$, unevenly distributed throughout the year, with a brief drought period during the summer months (Calvo-Fernández et al., 2017). Precipitation occurs mainly in the form of snow in late-autumn, winter and early-spring, with a snow melt period from April until the end of May. Bulk inorganic $\mathrm{N}$ deposition from 2011 to 2014 was $4.6 \mathrm{~kg} \mathrm{~N}^{-1} \mathrm{yr}^{-1}$ (Calvo-Fernández et al., 2017), and total $\mathrm{N}$ deposition ranges between 7.5 and $15 \mathrm{~kg} \mathrm{~N} \mathrm{ha}^{-1} \mathrm{yr}^{-1}$, according to the EMEP and CHIMERE models for Spain (García-Gómez et al., 2014). Therefore, total N deposition in the study area is either lower than or within the lowest critical load value estimated to threaten the persistence of European dry Calluna-heathlands (i.e., $10-20 \mathrm{~kg} \mathrm{~N} \mathrm{ha}^{-1} \mathrm{yr}^{-1}$; Bobbink et al., 2010; Hall et al., 2015). The study sites have Umbrisol soil (European Commission, 2005), characterized by sandy texture, high acidity $(\mathrm{pH}=3.9 \pm 0.14$; deionized water), and low fertility. Soil depth ranges from 30 to $50 \mathrm{~cm}$ (on sandstone and lutite) with the following horizons: $\quad \mathrm{O}_{\mathrm{if}} \quad(0-2 \mathrm{~cm}), \quad \mathrm{O}_{\mathrm{h}}$ 
$(2-5 \mathrm{~cm}), \mathrm{A}(5-20 \mathrm{~cm}), \mathrm{B}(20-40 \mathrm{~cm})$ or $\mathrm{A} / \mathrm{C}(20-35 \mathrm{~cm})$, and $\mathrm{C}$ (from 30 to $50 \mathrm{~cm}$ ). Therefore, soil conditions differ from the Podzol soils that are typical of many north-western European heathlands (Marcos et al., 2003). The soil of young heathland stands is covered by a shallow litter layer $(<1 \mathrm{~cm}$ depth) distributed in discontinuous patches, while a continuous and homogeneous litter layer $(2-3 \mathrm{~cm})$ characterizes the mature ones. The study sites are dominated by $\mathrm{Cal}$ luna (> 75\% cover; $20 \mathrm{~cm}$ height in young stands and $50 \mathrm{~cm}$ in mature stands), with Erica tetralix L. and Vaccinium myrtillus L. as the main accompanying species (Calvo et al., 2005). Lichens [Cladonia Hill ex Browne and Cetraria islandica (L.) Ach.] cover ca. $15 \%$ and different bryophyte species ca. $10 \%$. The bud burst of Calluna plants happens in June, and the vegetation growing season period is from June to October.

\subsection{Experimental design}

In each study site, we selected two heathland areas of different ages: (1) young stands rejuvenated by prescribed fire in 2005, i.e., 8 years old at the beginning of the experiment, and (2) mature stands showing the first signs of degeneration after 30-40 years of land use abandonment (i.e., building- and mature-phase; Gimingham, 1972). We established a total of $902 \mathrm{~m} \times 2 \mathrm{~m}$ plots and performed a manipulative experiment consisting of five different $\mathrm{N}$ fertilization treatments in addition to background atmospheric $\mathrm{N}$ deposition (i.e., 3 replicated plots per $\mathrm{N}$ treatment, age class, and site): $0 \mathrm{~kg} \mathrm{~N} \mathrm{ha}^{-1} \mathrm{yr}^{-1}$ (N0; control), $10 \mathrm{~kg} \mathrm{~N} \mathrm{ha}^{-1} \mathrm{yr}^{-1}$ (N10; low N load), $20 \mathrm{~kg} \mathrm{~N} \mathrm{ha}^{-1} \mathrm{yr}^{-1}$ (N20; medium load), and $50 \mathrm{~kg} \mathrm{~N}^{-1} \mathrm{yr}^{-1}$ (N50; high load) of solid granules of ammonium nitrate (Fertiberia S.A.; $27 \% \mathrm{NH}_{4} \mathrm{NO}_{3}$ purity) monthly added by hand to the soil surface in June-November from 2013 to 2015; and $56 \mathrm{~kg} \mathrm{~N} \mathrm{ha}^{-1} \mathrm{yr}^{-1}$ (N56; chronic high $\mathrm{N}$ load) added monthly in May-October from 2005 to 2015 equivalent to the highest predicted $\mathrm{N}$ input by 2050 for southern Europe (Galloway et al., 2004) [i.e., corresponding to ca. two times the maximum total $\mathrm{N}$ deposition levels in the study area at the beginning of the experiment: Rivero Fernández et al., 1996; and to ca. four times the current maximum total $\mathrm{N}$ deposition levels in the study area: García-Gómez et al., 2014]. Solid granules release ammonium and nitrate slowly over the soil surface, and have been used in previous studies on heathlands responses to N fertilization (e.g., Cuesta et al., 2008; Marcos et al., 2003, 2009; Taboada et al., 2016). The young and mature experimental plots were randomly assigned to the $\mathrm{N}$ treatments at each study site.

During the experiment, infestations of Calluna plants by the larvae of the heather beetle, Lochmaea suturalis (Thomson, 1866), occurred in June 2008 and August 2015 at one of the three heathland sites (Riopinos II) (personal observations), but only ca. $0.5 \%$ of the heathland area was infested (see Taboada et al., 2016 for further information). In the 2008 outbreak event, only the chronic high $\mathrm{N}$ treatment (N56) mature plots were severely defoliated, but the consumed plants were not killed and regenerated the next growing season following the beetle's attack. In the 2015 outbreak event, both mature and young N56 plots were marginally affected by the beetle's defoliation. After the beetle's infestation, however, the defoliated plants at the N56 mature plots were debilitated and suffered from subsequent physical damage caused by livestock trampling. We did not observe further severe damage to the vegetation due to other environmental stress factors like frost or drought.

\subsection{Sampling methods}

We collected three soil samples (topsoil, $0-5 \mathrm{~cm}$ below the litter layer) in each $2 \mathrm{~m} \times 2 \mathrm{~m}$ plot in September 2014 and 2015 using a soil auger, which were combined to obtain one soil sample per plot and year. Fresh soil samples were brought to the laboratory in air-tight plastic bags, and immediately sieved $(2 \mathrm{~mm} \varnothing)$ and divided in two subsamples. The first subsample was air-dried and stored in a polyethylene bag for total $\mathrm{N}$, organic $\mathrm{C}$, and available $\mathrm{P}$ analyses. We also calculated the soil $\mathrm{C}: \mathrm{N}$ ratio. The second subsample was stored at $-18{ }^{\circ} \mathrm{C}$ in a polyethylene bag for extractable $\mathrm{N}_{-} \mathrm{NH}_{4}{ }^{+}$and $\mathrm{N}-\mathrm{NO}_{3}{ }^{-}$, enzymatic activities, and microbial biomass $\mathrm{C}$ and $\mathrm{N}$ analyses. The thawing procedure was done at $4{ }^{\circ} \mathrm{C}$ in a refrigerator.

We randomly selected 5-10 Calluna plants in each plot to obtain a sufficient quantity of fine roots per plot to determine the extent of root ericoid mycorrhizal colonization in August 2015. Fine roots were manually isolated using a $400 \times$ optical microscope (M20-42149, Wild Heerbrugg, Switzerland), and subsequently stored at $-18^{\circ} \mathrm{C}$ until analysis.

To determine Calluna plant and litter $\mathrm{N}$ and $\mathrm{P}$ contents and calculate N:P ratios, we collected ten young Calluna apical shoots and three $5 \mathrm{~cm} \times 5 \mathrm{~cm}$ litter layer (i.e., dead plant leaves fell to the ground) samples from each $2 \mathrm{~m} \times 2 \mathrm{~m}$ plot in July 2014 and 2015, which were combined to obtain one shoot or litter sample per plot and year. The shoots and litter samples were dried at $40{ }^{\circ} \mathrm{C}$ for $48 \mathrm{~h}$, pulverized (Pulverisette 14, Fritsch, Oberstein, Germany) and sieved (200 $\mu \mathrm{m})$ before nutrient analyses.

\subsection{Analytical methods}

Soil total N was determined by a Kjeldhal procedure (Bremner and Mulvaney, 1982), with four reagent blanks used for each digestion batch (eight soil samples). Organic $\mathrm{C}$ was determined using wet oxidation with potassium dichromate (Ministerio de Agricultura, Pesca y Alimentación, 1986), and available P following the Bray-Kurtz method (Kalra and Maynard, 1991). Two reagent blanks were used for each batch of organic $\mathrm{C}$ determination, and one reagent blank was used for each calibration line of available $\mathrm{P}$. The $\mathrm{N}_{-} \mathrm{NH}_{4}{ }^{+}$and $\mathrm{N}-\mathrm{NO}_{3}{ }^{-}$ were extracted with $2 \mathrm{M} \mathrm{KCl}$ (ratio 1:10 soil-extractant) according to Keeney and Nelson (1982), and measured by steam distillation with a micro-Kjeldhal automatic analyzer using the Bremner (1965) method. Four reagent blanks were used for each batch of steam distillation (ten soil samples).

Soil acid phosphatase and $\beta$-glucosidase activities were determined colorimetrically as the amount of $p$-nitrophenol $(p-\mathrm{NP})$ produced after incubation of 0.5 and $1 \mathrm{~g}$ of soil $\left(37^{\circ} \mathrm{C}, 1 \mathrm{~h}\right)$ with $p$-nitrophenyl-phosphate and $p$-nitrophenyl- $\beta$-D-glucopyranoside substrates, respectively (Tabatabai, 1982; Tabatabai and Bremner, 1969). The $p$-NP formed was determined in a spectrophotometer at $400 \mathrm{~nm}$ (UV-1700 PharmaSpec, Shimadzu, Kyoto, Japan). Urease activity was determined following Kandeler and Gerber (1988) as the amount of $\mathrm{N}_{-} \mathrm{NH}_{4}{ }^{+}$released from $1 \mathrm{~g}$ of soil after incubation $\left(37^{\circ} \mathrm{C}, 2 \mathrm{~h}\right)$ with urea substrate. The $\mathrm{N}_{-} \mathrm{NH}_{4}^{+}$released was measured colorimetrically at $690 \mathrm{~nm}$. One sample blank for each soil sample was used in the determination of the acid phosphatase and urease activities. Two replicated measures and two sample blanks for each soil sample were used for the $\beta$-glucosidase determination. Besides, one reagent blank was used to build up each calibration line for colorimetric analyses. For $\beta$-glucosidase activity, one calibration line was built up for each soil sample using $p$-NP standard solutions incubated together with the soil.

Soil microbial biomass $\mathrm{C}$ and $\mathrm{N}$ were determined by the Fumigation-Extraction method (Vance et al., 1987). Estimation of soil microbial biomass $\mathrm{N}$ was performed by titration of total extracted $\mathrm{N}$ according to Brookes et al. (1985), using a $\mathrm{K}_{\mathrm{EN}}$ factor of 0.45 . Estimation of soil microbial biomass $\mathrm{C}$ was performed by wet digestion ac- 
cording to Vance et al. (1987), using a $\mathrm{K}_{\mathrm{EC}}$ factor of 0.38 . Four and two reagent blanks were used for each analysis batch of soil microbial biomass $\mathrm{N}$ (eight soil samples) and $\mathrm{C}$ (ten soil samples), respectively.

The amount of ericoid mycorrhizal colonization in Calluna roots was quantified in $0.5 \mathrm{~g}$ of the finest roots. The method consisted of a first step of staining roots with a solution of ink-vinegar (5\%) according to Vierheilig et al. (1998), using Sheaffer black ink. The second step was the measurement of the percentage of roots colonized by ericoid mycorrhizae using the intersection method by McGonigle et al. (1990), with a $400 \times$ optical microscope (M20-42149, Wild Heerbrugg, Switzerland).

Calluna shoot and litter $\mathrm{N}$ contents were determined by the Kjeldahl digestion method (BÜCHI Digestion Unit K-435, Flawil, Switzerland) coupled to a tritator (Metrohm 719 S tritino, Herisau, Switzerland). Calluna shoot and litter P contents were determined by digestion with $\mathrm{HNO}_{3}(65 \%)$ and heating at $550{ }^{\circ} \mathrm{C}$, and measured with ICP-OES (Optima 2000 DV, Perkin Elmer). Four reagent blanks were used for each digestion batch of shoot and litter $\mathrm{N}$ contents (eight shoot/litter samples), and one reagent blank was used for each calibration line in the colorimetric determination of shoot and litter P contents.

\subsection{Data analyses}

We fitted linear mixed models (LMMs) with a repeated measures design to test the effects of $\mathrm{N}$ fertilization on soil properties (nutrient contents, enzymatic activities, and microbial biomass), Calluna plants and litter (nutrient contents), mediated by time and the age of heathland vegetation. The response variables in the models were: (1) soil total $\mathrm{N}$, (2) soil organic $\mathrm{C}$, (3) soil $\mathrm{C}: \mathrm{N}$ ratio, (4) soil available $\mathrm{P},(5)$ soil extractable $\mathrm{N}_{-} \mathrm{NH}_{4}{ }^{+}$, (6) soil extractable $\mathrm{N}_{-} \mathrm{NO}_{3}{ }^{-}$, (7) acid phosphatase activity, (8) urease activity, (9) $\beta$-glucosidase activity, (10) soil microbial biomass C, (11) soil microbial biomass N, (12) Calluna shoot N content, (13) Calluna shoot P content, (14) Calluna shoot N:P ratio, (15) litter $\mathrm{N}$ content, (16) litter $\mathrm{P}$ content, and (17) litter $\mathrm{N}: \mathrm{P}$ ratio. We modelled the response variables assuming a Gaussian error distribution, using the identity link function. The predictor variables (fixed factors) were age of Calluna plants (young and mature), the $\mathrm{N}$ treatment (N0, N10, N20, N50, and N56), and their interaction. The interaction term was retained in the models only when significant. Statistical significance was considered when $\mathrm{p}<0.05$; and significance levels of the difference between each $\mathrm{N}$ fertilization treatment (N10, N20, N50, and N56) and the control treatment (N0) obtained directly from the model summary outputs are indicated on the figures. The identity of the heathland sites and the sampling years were included in the models as random factors. The normality and homogeneity of the model residuals were checked using diagnostic plots. We obtained predicted values of the response variables from the models for each heathland age and $\mathrm{N}$ treatment, without taking the uncertainty of the random effects parameters into account, and computed $95 \%$ confidence intervals based on a normal approximation.

We also evaluated the effects of $\mathrm{N}$ fertilization on root mycorrhizal colonization by performing a generalized linear model (GLM) with the percentage of Calluna roots colonized by ericoid mycorrhizae as the response variable, and the age of Calluna plants (young and mature), the $\mathrm{N}$ treatment (N0, N10, N20, N50, and N56), and their interaction as the predictor variables. The interaction term was retained in the model only if significant. Statistical significance was considered when $\mathrm{p}<0.05$; and significance levels of the difference between each $\mathrm{N}$ fertilization treatment (N10, N20, N50, and N56) and the control treatment (N0) obtained directly from the model summary outputs are indicated on the figure. We modelled the response variable following a quasi-Poisson error distribution to account for overdispersion, using the log link function. We obtained model predicted values of the percentage of roots colonized by ericoid mycorrhizae for each heathland age and $\mathrm{N}$ treatment.

All data analyses were carried out with R software, version 3.3.1 (R Core Team, 2016) using the 'stats', 'lme4' (Bates et al., 2015) and 'ImerTest' (Kuznetsova et al., 2016) packages.

\section{Results}

\subsection{Soil nutrient contents}

Soil extractable $\mathrm{N}_{-} \mathrm{NH}_{4}^{+}$content significantly increased in response to the addition of $\mathrm{N}$, but only in the N56 treatment (Fig. 1; Table 1). However, there were no significant differences for soil extractable $\mathrm{N}_{-} \mathrm{NO}_{3}^{-}$(Fig. 1; Table 1). Soil N-NH${ }_{4}^{+}$content was ca. 10-15-fold higher than $\mathrm{N}_{-} \mathrm{NO}_{3}{ }^{-}$in each $\mathrm{N}$ treatment. Besides, significantly higher $\mathrm{N}^{-\mathrm{NO}_{3}}{ }^{-}$contents were observed in young heathlands than in mature ones. No changes were detected for soil available $\mathrm{P}$ after the addition of $\mathrm{N}$, while significantly higher available $\mathrm{P}$ values were recorded in young heathlands, compared to mature ones (Fig. 1; Table 1). No significant differences were found for soil total N, organic $\mathrm{C}$, or $\mathrm{C}: \mathrm{N}$ ratio with regard to the $\mathrm{N}$ treatments and heathland ages (Table 1).
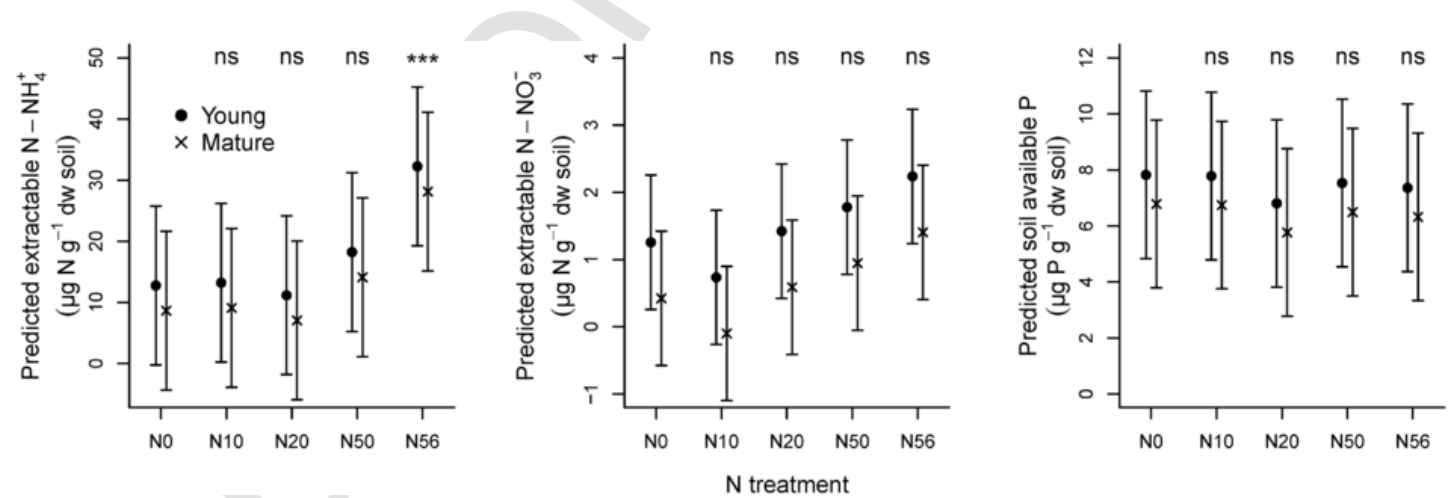

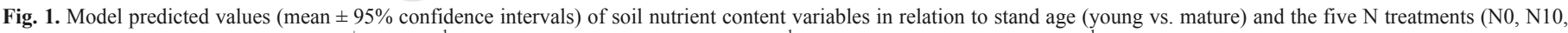

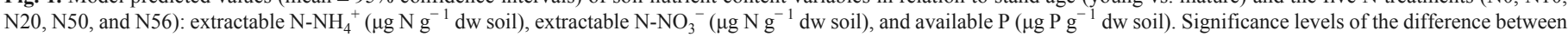

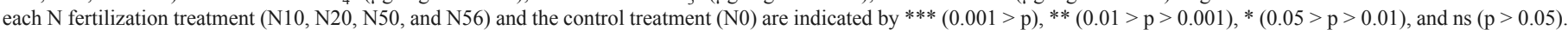


Table 1

LMM results ['anova()' outputs] for the effects of heathland age (young vs mature) and $\mathrm{N}$ treatment (N0, N10, N20, N50, and N56) on soil nutrient contents, soil enzymatic activities and soil microbial biomass nutrient contents. The interaction term (age $\times \mathrm{N}$ treatment) was retained in the models only when significant. Standard deviations (SD) and variance components (\%) of the random effects (identity of the heathland sites and the sampling years) are given. $\mathrm{Df}=$ degrees of freedom. Significant $\mathrm{p}$-values are in bold face.

\begin{tabular}{|c|c|c|c|c|c|c|c|}
\hline \multirow[t]{2}{*}{$\begin{array}{l}\text { Response } \\
\text { variable }\end{array}$} & \multicolumn{4}{|c|}{ Fixed effects } & \multicolumn{3}{|c|}{ Random effects } \\
\hline & $\begin{array}{l}\text { Predictor } \\
\text { variable }\end{array}$ & Df & $\begin{array}{l}\mathrm{F} \\
\text { value }\end{array}$ & $\mathrm{p}$ value & Variable & SD & Variance \\
\hline \multicolumn{8}{|c|}{ Soil nutrient contents } \\
\hline \multirow[t]{3}{*}{ Total N } & Age & 1 & 0.02 & 0.887 & Site & 0.103 & 34.90 \\
\hline & $\begin{array}{l}\mathrm{N} \\
\text { treatment }\end{array}$ & 4 & 2.01 & 0.095 & Year & 0.035 & 11.97 \\
\hline & & & & & Residual & 0.157 & 53.13 \\
\hline \multirow[t]{3}{*}{ Organic $\mathrm{C}$} & Age & 1 & 0.03 & 0.855 & Site & 0.307 & 9.65 \\
\hline & $\begin{array}{l}\mathrm{N} \\
\text { treatment }\end{array}$ & 4 & 1.56 & 0.186 & Year & 0.237 & 7.45 \\
\hline & & & & & Residual & 2.633 & 82.90 \\
\hline \multirow[t]{3}{*}{$\mathrm{C}: \mathrm{N}$ ratio } & Age & 1 & 1.55 & 0.215 & Site & 5.741 & 55.70 \\
\hline & $\begin{array}{l}\mathrm{N} \\
\text { treatment }\end{array}$ & 4 & 0.58 & 0.677 & Year & 0.000 & 0.00 \\
\hline & & & & & Residual & 4.566 & 44.30 \\
\hline \multirow{3}{*}{$\begin{array}{l}\text { Extractable } \\
\mathrm{N}_{-} \mathrm{NH}_{4}^{+}\end{array}$} & Age & 1 & 2.97 & 0.087 & Site & 3.017 & 11.22 \\
\hline & $\begin{array}{l}\mathrm{N} \\
\text { treatment }\end{array}$ & 4 & 10.46 & $<0.001$ & Year & 7.823 & 29.10 \\
\hline & & & & & Residual & 16.047 & 59.68 \\
\hline \multirow{3}{*}{$\begin{array}{l}\text { Extractable } \\
\mathrm{N}^{-\mathrm{NO}_{3}}{ }^{-}\end{array}$} & Age & 1 & 4.17 & 0.043 & Site & $8.5 \times 10^{-8}$ & 0.00 \\
\hline & $\begin{array}{l}\mathrm{N} \\
\text { treatment }\end{array}$ & 4 & 1.53 & 0.196 & Year & 0.000 & 0.00 \\
\hline & & & & & Residual & 2.737 & 100.00 \\
\hline \multirow[t]{3}{*}{ Available P } & Age & 1 & 5.08 & 0.026 & Site & 2.102 & 34.23 \\
\hline & $\begin{array}{l}\mathrm{N} \\
\text { treatment }\end{array}$ & 4 & 0.64 & 0.636 & Year & 0.946 & 15.40 \\
\hline & & & & & Residual & 3.094 & 50.37 \\
\hline \multicolumn{8}{|c|}{ Soil enzymatic activities } \\
\hline \multirow{3}{*}{$\begin{array}{l}\text { Acid } \\
\text { phosphatase }\end{array}$} & Age & 1 & 2.98 & 0.086 & Site & 0.387 & 6.26 \\
\hline & $\begin{array}{l}\mathrm{N} \\
\text { treatment }\end{array}$ & 4 & 3.85 & 0.005 & Year & 1.454 & 23.54 \\
\hline & & & & & Residual & 4.335 & 70.20 \\
\hline \multirow[t]{3}{*}{ Urease } & Age & 1 & 0.59 & 0.444 & Site & 0.653 & 12.41 \\
\hline & $\begin{array}{l}\mathrm{N} \\
\text { treatment }\end{array}$ & 4 & 1.59 & 0.178 & Year & 0.946 & 17.99 \\
\hline & & & & & Residual & 3.661 & 69.60 \\
\hline \multirow{3}{*}{$\begin{array}{l}\beta- \\
\text { glucosidase }\end{array}$} & Age & 1 & 0.86 & 0.354 & Site & 0.281 & 6.96 \\
\hline & $\begin{array}{l}\mathrm{N} \\
\text { treatment }\end{array}$ & 4 & 0.73 & 0.572 & Year & 1.116 & 27.59 \\
\hline & & & & & Residual & 2.646 & 65.45 \\
\hline \multicolumn{8}{|c|}{ Soil microbial biomass nutrient contents } \\
\hline \multirow{3}{*}{$\begin{array}{l}\text { Microbial } \\
\text { biomass } \mathrm{C}\end{array}$} & Age & 1 & 3.15 & 0.078 & Site & 319.700 & 24.38 \\
\hline & $\begin{array}{l}\mathrm{N} \\
\text { treatment }\end{array}$ & 4 & 1.75 & 0.141 & Year & 279.500 & 21.31 \\
\hline & & & & & Residual & 712.200 & 54.31 \\
\hline \multirow{3}{*}{$\begin{array}{l}\text { Microbial } \\
\text { biomass } \mathrm{N}\end{array}$} & Age & 1 & 9.61 & 0.002 & Site & 19.650 & 16.80 \\
\hline & $\begin{array}{l}\mathrm{N} \\
\text { treatment }\end{array}$ & 4 & 1.29 & 0.275 & Year & 30.070 & 25.71 \\
\hline & & & & & ual & 67.24 & 57.49 \\
\hline
\end{tabular}

\subsection{Enzymatic activities}

Acid phosphatase enzyme activity significantly increased in response to $\mathrm{N}$ addition, particularly in the N56 treatment, and to a lesser extent in the N10 treatment (Fig. 2; Table 1). However, there were no significant differences in acid phosphatase activity related to heathland age. We found significant differences in urease enzyme activity after the addition of $\mathrm{N}$ in the N10 treatment (Fig. 2; Table 1); but no significant differences in relation to heathland age. $\beta$-Glucosidase enzyme activity did not show significant changes in relation to $\mathrm{N}$ addition and heathland age (Fig. 2; Table 1).

\subsection{Soil microbial biomass}

Soil microbial biomass $\mathrm{C}$ and $\mathrm{N}$ did not show any significant changes in response to the addition of $\mathrm{N}$ (Fig. 3; Table 1). Microbial biomass $\mathrm{N}$ content was, however, significantly higher in young heathlands than in mature ones.

\subsection{Calluna root mycorrhizal colonization}

The percentage of Calluna roots colonized by ericoid mycorrhizae was significantly higher in the N56 treatment (Fig. 4; Table 2). Moreover, the responses of mycorrhizal colonization to the $\mathrm{N}$ treatments were age-related, shown by the significant 'age $\times \mathrm{N}$ treatment' interaction, with a higher percentage of colonized roots in young heathlands for the control (N0), N10 and N20 treatments, and in mature ones for the N50 and N56 treatments.

\subsection{Calluna shoot and litter nutrient contents}

Both Calluna shoot $\mathrm{N}$ and $\mathrm{P}$ contents significantly increased as a result of $\mathrm{N}$ fertilization, particularly under the N56 treatment (Fig. 5; Table 3). Also, young Calluna plants had significantly higher shoot $\mathrm{N}$ and $\mathrm{P}$ contents than mature ones.

Litter N content significantly increased in the N50 and N56 treatments (Fig. 5; Table 3). Besides, higher litter $\mathrm{N}$ content was found in young heathlands than in mature ones. A significant 'age $\times \mathrm{N}$ treatment' interaction was found for litter P content (Fig. 5; Table 3), with higher values in young heathlands for the N20, N50 and N56 treatments, and in mature ones for the control treatment (N0).

Shoot and litter N:P ratios significantly increased after $\mathrm{N}$ addition, and achieved maximum values in the N50 and N56 treatments, respectively, for both heathland ages (Fig. 5; Table 3).

\section{Discussion}

\subsection{Time- and dose-related effects of $N$ fertilization}

Several previous field-scale surveys and N-fertilization experiments carried out in north-western European heathlands provided strong evidence of the impact of $\mathrm{N}$ deposition on soil nutrients, indicated by an increase in extractable $\mathrm{N}_{-} \mathrm{NH}_{4}{ }^{+}$and $\mathrm{N}_{-} \mathrm{NO}_{3}{ }^{-}$under high-N inputs (e.g., Phoenix et al., 2012; Southon et al., 2013). Similar results were also reported from other systems such as subalpine forests (Boot et al., 2016), permafrost peatlands (Song et al., 2017), and semiarid Mediterranean shrublands (Ochoa-Hueso et al., 2013, 2014). In Cantabrian marginal montane heathlands, we only observed an increase in soil extractable $\mathrm{N}_{-} \mathrm{NH}_{4}{ }^{+}$in the chronic high $\mathrm{N}$ treatment (N56; 10 years), but no changes in soil extractable $\mathrm{N}^{-\mathrm{NO}_{3}}{ }^{-}$. These results suggest that in these montane heathlands a shift in soil extractable $\mathrm{N}$ is only to be expected under high $\mathrm{N}$ loading. This coincides with findings from upland and lowland heaths, in which significant responses of soil $\mathrm{N}-\mathrm{NO}_{3}{ }^{-}$and $\mathrm{N}-\mathrm{NH}_{4}{ }^{+}$were mainly observed at the highest $\mathrm{N}$ deposition rates (up to $120 \mathrm{~kg} \mathrm{~N}^{-1} \mathrm{yr}^{-1}$; Phoenix et al., 2012). Moreover, soil extractable $\mathrm{N}_{-} \mathrm{NH}_{4}{ }^{+}$contents were about 10 to 15 -fold higher than $\mathrm{N}^{-\mathrm{NO}_{3}}{ }^{-}$in all the montane heathland stands, 

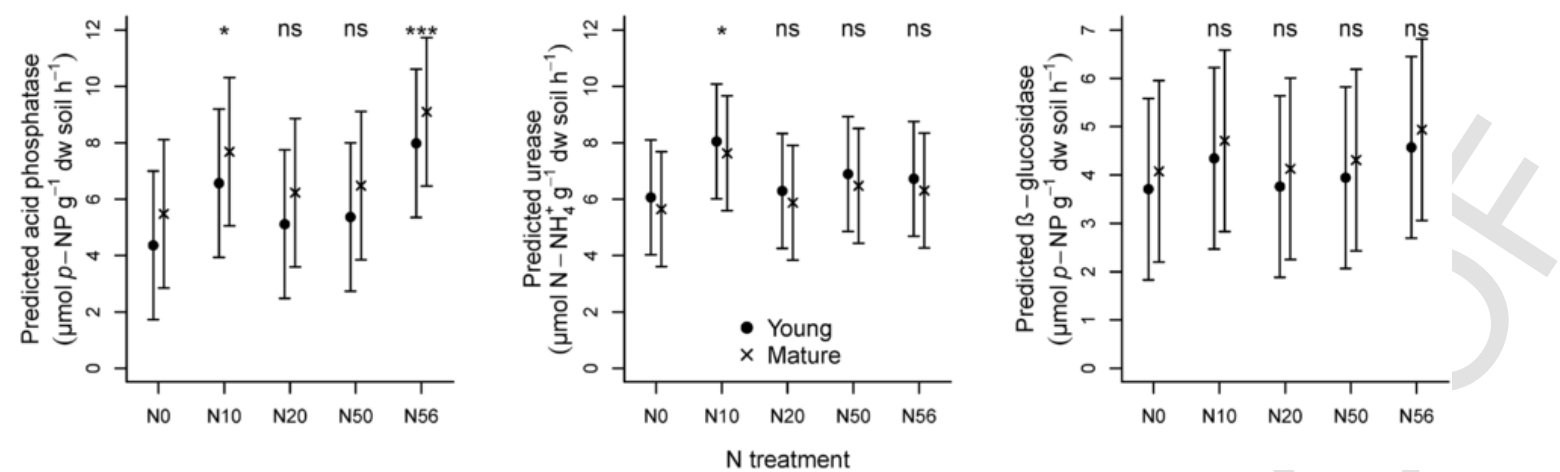

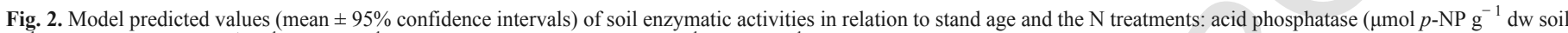

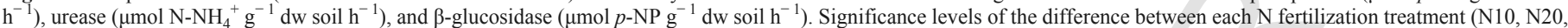
$\mathrm{N} 50$, and N56) and the control treatment (N0) are indicated by *** $(0.001>\mathrm{p}),{ }^{* *}(0.01>\mathrm{p}>0.001),{ }^{*}(0.05>\mathrm{p}>0.01)$, and ns $(\mathrm{p}>0.05)$.
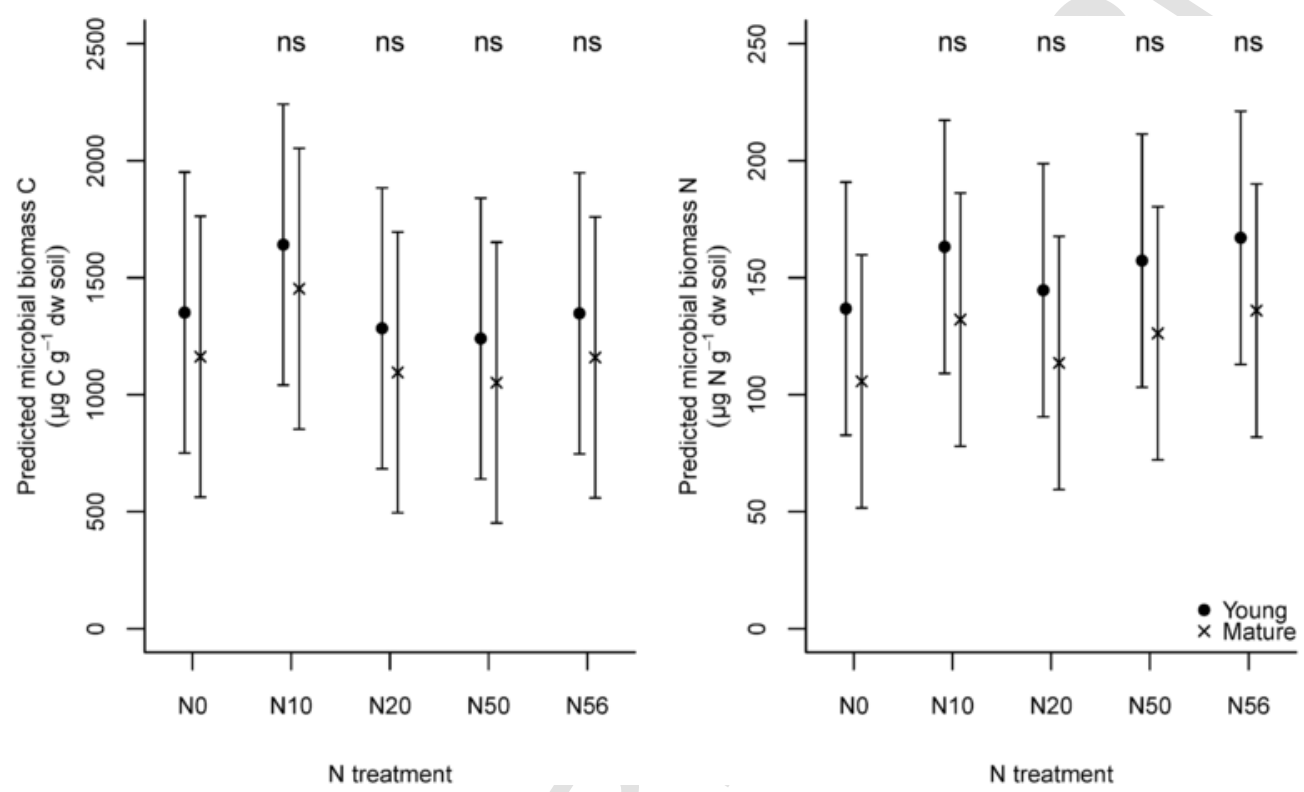

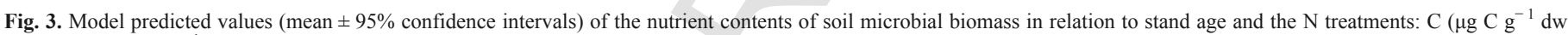

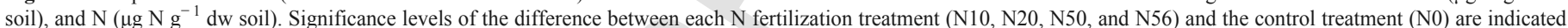
by $* * *(0.001>\mathrm{p}), * *(0.01>\mathrm{p}>0.001), *(0.05>\mathrm{p}>0.01)$, and $\mathrm{ns}(\mathrm{p}>0.05)$.

and particularly in the chronic high $\mathrm{N}$ treatment (N56), as was also reported by Boot et al. (2016) in a subalpine forest ecosystem under long-term (17-year) $\mathrm{N}$ loading. It is very likely that the unique environmental conditions [low soil $\mathrm{pH}$ values (3.9), low winter temperatures and summer droughts] of the heathlands studied had inhibited nitrification [net nitrification rates around $0.25-1.5 \mathrm{~g} \mathrm{~N} \mathrm{~m}^{-2}$ month $^{-1}$ (unpublished data)] (Stevens et al., 2011), resulting in a notable accumulation of soil extractable $\mathrm{N}_{-} \mathrm{NH}_{4}{ }^{+}$(Nielsen et al., 2009; Stevens et al., 2011). On the other hand, soil organic $\mathrm{C}$, total $\mathrm{N}$, and available $\mathrm{P}$ were not affected by $\mathrm{N}$ fertilization, probably due to the slow rate of change in the $\mathrm{C}$ and $\mathrm{N}$ pools in response to increased $\mathrm{N}$ availability (Ochoa-Hueso et al., 2013, 2014). Therefore, it might take $>10$ years of $\mathrm{N}$ fertilization to alter the soil $\mathrm{C}$ and $\mathrm{N}$ pools in montane Calluna-heathlands due to the short period of microbial physiological activity, since chronic high $\mathrm{N}$ loads might result in the production of $\mathrm{N}$-rich litter that would be very slowly decomposed by soil microbes and incorporated into the topsoil stock of C (de Vries et al., 2009) and N (Pilkington et al., 2005b).
The observed N-driven changes in soil nutrient contents may also be related to the alteration in the functioning of soil microorganisms and the resulting soil extracellular enzyme activities, determined by the levels of metabolic nutrient demands (Jian et al., 2016; Ochoa-Hueso et al., 2011; Sinsabaugh and Follstad, 2012; Song et al., 2017). We reported a significant rise in the activity of the acid phosphatase enzyme in response to $\mathrm{N}$ fertilization, especially in the chronic high N treatment (N56). Johnson et al. (1998) and Pilkington et al. (2005a) also found that the greatest soil acid phosphatase activity corresponded to their highest long-term $\mathrm{N}$-addition treatment (120 kg N ha $\mathrm{kr}^{-1}$ ) in upland heathlands; whereas a $\mathrm{N}$ deposition load of only $10 \mathrm{~kg} \mathrm{~N} \mathrm{ha}^{-1} \mathrm{yr}^{-1}$ was sufficient to increase the acid phosphatase activity in a low-alpine heathland (Papanikolaou et al., 2010). The observed increase in soil acid phosphatase activity in our studied montane heathlands could be explained by changes in soil nutrients (i.e., higher $\mathrm{N}$ availability), resulting in $\mathrm{P}$ deficiency for plants and soil microbes in low available $\mathrm{P}$ status of heathland soils (Ochoa-Hueso et al., 2014; Phoenix et al., 2003; Pilkington et al., 2005a). This nutritional imbalance could be compensated for by

the

microbial 


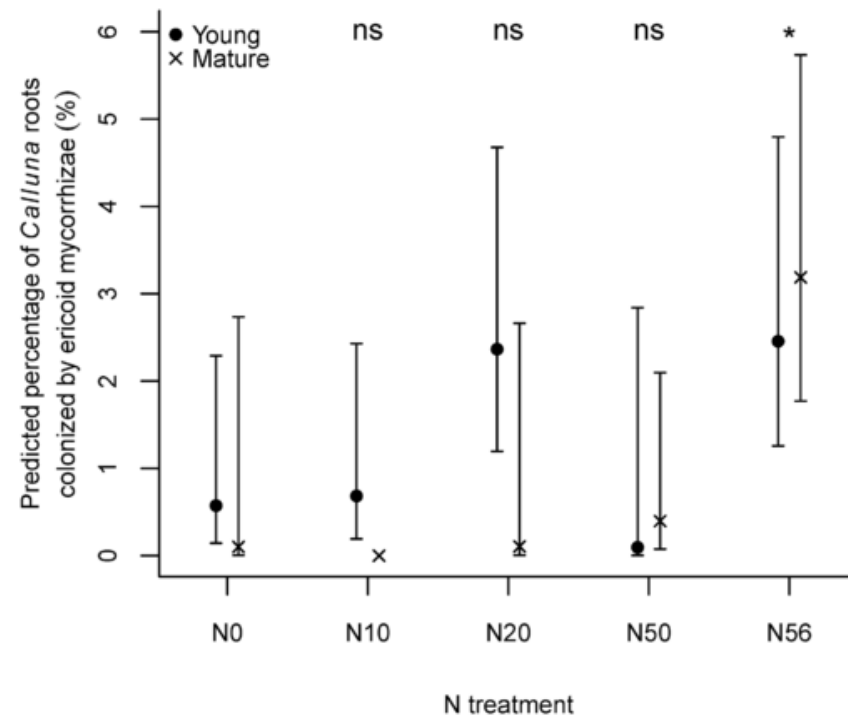

Fig. 4. Model predicted values (mean $\pm 95 \%$ confidence intervals) of Calluna mycorrhizal colonization (\% roots colonized by ericoid mycorrhizae) in relation to stand age and the $\mathrm{N}$ treatments. Significance levels of the difference between each $\mathrm{N}$ fertilization treatment $(\mathrm{N} 10, \mathrm{~N} 20, \mathrm{~N} 50$, and N56) and the control treatment (N0) are indicated by $* * *(0.001>p), * *(0.01>p>0.001), *(0.05>p>0.01)$, and $n s(p>0.05)$.

Table 2

GLM results ['anova()' output] for the effects of heathland age (young, mature) and N treatment (N0, N10, N20, N50, and N56) on Calluna mycorrhizal colonization by ericoid fungi. $\mathrm{Df}=$ degrees of freedom. Significant $\mathrm{p}$-values are in bold face.

\begin{tabular}{llllll}
\hline Response variable & $\begin{array}{l}\text { Predictor } \\
\text { variable }\end{array}$ & Df & Deviance & $\begin{array}{l}\text { Residual } \\
\text { deviance }\end{array}$ & p value \\
\hline $\begin{array}{l}\text { Mycorrhizal colonization } \\
\begin{array}{l}\text { Calluna } \text { roots colonized by } \\
\text { ericoid mycorrhizae }\end{array}\end{array}$ & NULL & & & 284.55 & \\
& Age & 1 & 5.18 & 279.37 & 0.156 \\
& N treatment & 4 & 76.57 & 202.80 & $<\mathbf{0 . 0 0 1}$ \\
& $\begin{array}{c}\text { Age:N } \\
\text { treatment }\end{array}$ & 4 & 32.24 & 170.57 & $\mathbf{0 . 0 1 4}$ \\
& & & & \\
\hline
\end{tabular}

and plant excretion of phosphatase enzymes required for the mineralization of organic P (López-Poma and Bautista, 2014; Pilkington et al., 2005a; Rowe et al., 2008); since phosphatase activity can be modulated through enzyme excretion or activity inhibition depending on soil P availability (Johnson et al., 1999; López-Poma and Bautista, 2014; Phoenix et al., 2003).

Soil urease activity, however, did not change in response to $\mathrm{N}$ fertilization, as high soil inorganic $\mathrm{N}$ availability inhibited this enzymatic activity through a reduced synthesis and release of urease enzyme by soil microbes (Ajwa et al., 1999; Fatemi et al., 2016; Sinsabaugh and Follstad, 2012; Song et al., 2017). Likewise, we did not find a significant response of $\beta$-glucosidase enzyme activity to $\mathrm{N}$ fertilization, similarly to the findings from low-alpine heathlands (Papanikolaou et al., 2010), forests (Boot et al., 2016; Fatemi et al., 2016), and peatlands (Song et al., 2017). This lack of response is most likely the result of (1) the unaltered soil organic $\mathrm{C}$ contents, suggesting that the activity of this enzyme is substrate-dependent (Cenini et al., 2016; López-Poma and Bautista, 2014), and (2) of the fact that soil microbial communities, which predominantly synthetize $\beta$-glucosidase enzyme, are not limited by soil $\mathrm{C}$ availability (Sinsabaugh and Follstad, 2012). Indeed, we found no significant changes in soil microbial biomass $\mathrm{C}$ and $\mathrm{N}$ in response to increased $\mathrm{N}$ availability, in agreement with other studies from temperate (Nielsen et al., 2009) and arctic (< 10 years of N inputs; Rinnan et al., 2007) heathlands; but different from previous studies in which both or either soil microbial biomass $\mathrm{N}$ or $\mathrm{C}$ increased (e.g., upland and lowland heathlands: Johnson et al., 1998; Power et al., 2006; temperate forests: Du et al., 2014) or decreased (e.g., peatlands: Song et al., 2017; forests: Boot et al., 2016). Our results support the fact that there is a reduced microbial acquisition and immobilization of nutrients that maintains the low soil fertility status of montane heathlands (Nielsen et al., 2009). Furthermore, the distinctive climatic conditions of our montane study area, characterized by low temperatures, prolonged snow cover until late-spring, and a brief summer drought (Calvo-Fernández et al., 2017), could have also influenced the low rates of soil microbial nutrient acquisition (Calvo-Fernández et al., 2015; Hagedorn et al., 2010). Moreover, previous studies indicated that longer-term ( $>10$-year) $\mathrm{N}$ inputs may be required for producing significant shifts in the nutrient content of the soil microbial biomass in heathlands due to the slow organic matter decomposition rates (Contosta et al., 2015; Rinnan et al., 2007).

As we hypothesized, $\mathrm{N}$ addition increased Calluna tissue $\mathrm{N}$ and $\mathrm{P}$ contents, especially in the chronic high $\mathrm{N}$ treatment (N56), and Calluna $\mathrm{N}: \mathrm{P}$ ratio, particularly in the high (N50) and chronic high (N56) $\mathrm{N}$ treatments. This is in agreement with previous $\mathrm{N}$-fertilization experiments and field-scale surveys performed in north-western European heathlands (Jones and Power, 2012; Pilkington et al., 2005b; Southon et al., 2012). According to the N:P threshold values proposed by Güsewell (2004) in terrestrial plant communities (i.e., N:P ratio $<10$ for $\mathrm{N}$-limited and $>20$ for $\mathrm{P}$-limited systems), our results indicated that montane Calluna heathlands subjected to long-term $\mathrm{N}$ fertilization may not be limited by either $\mathrm{N}$ or $\mathrm{P}$ (see Britton et al., 2008; Friedrich et al., 2011; von Oheimb et al., 2010). The reported increase in Calluna tissue $\mathrm{N}$ and $\mathrm{P}$ contents may be related to the observed increases in litter N and P contents (Jones and Power, 2012), likely due to the inputs of the $\mathrm{N}$ and $\mathrm{P}$ enriched shoots to the litter layer (Pilkington et al., 2005b). However, the increase in Calluna tissue and litter P contents did not alter soil available P content, since all newly-mineralised soil P may have been immediately taken up by the plants or incorporated into the soil microbial biomass to satisfy their enhanced $\mathrm{P}$ demands in response to the addition of $\mathrm{N}$ (Friedrich et al., 2011; Johnson et al., 1998, 1999; Jones and Power, 2015; Rowe et al., 2008); or even immobilized by iron and aluminium (hydr)oxides in acid soils (Kooijman et al., 1998). Particularly, the enhanced $\mathrm{P}$ demand of Calluna plants in the chronic high N treatment (N56) in low available $P$ status of heathland soils was probably satisfied by: (1) the observed increase in the activity of soil acid phosphatase enzyme that is necessary for the mineralization of soil organic P (López-Poma and Bautista, 2014; Pilkington et al., 2005a; Rowe et al., 2008); and by (2) the observed increase in the degree of Calluna root mycorrhizal colonization by ericoid fungi that might enhance plant nutrient uptake from the widely extended hyphae network (Díaz et al., 2006; Jones and Power, 2012; Rowe et al., 2008), including the nutrient uptake of organic forms (Johnson et al., 2005). Besides, ericoid mycorrhizal fungi are able to produce and release acid phosphatase enzyme to provide inorganic P (Cairney and Burke, 1998). By contrast, other heathland studies showed that increasing $\mathrm{N}$ loadings tended to decrease the ericoid mycorrhizal colonization in Calluna roots due to the little benefit of mycorrhizal fungi in non-limited nutrient conditions (Yesmin et al., 1996). Moreover, a decrease in root mycorrhizal colonization with increasing $\mathrm{N}$ inputs was also observed by Camenzind et al. (2016) in an $\mathrm{N}$-fertilization experiment in montane forests, pointing out that the response of mycorrhizal fungi to $\mathrm{N}$ loading depends on the soil fertility status previous to fertilization. 

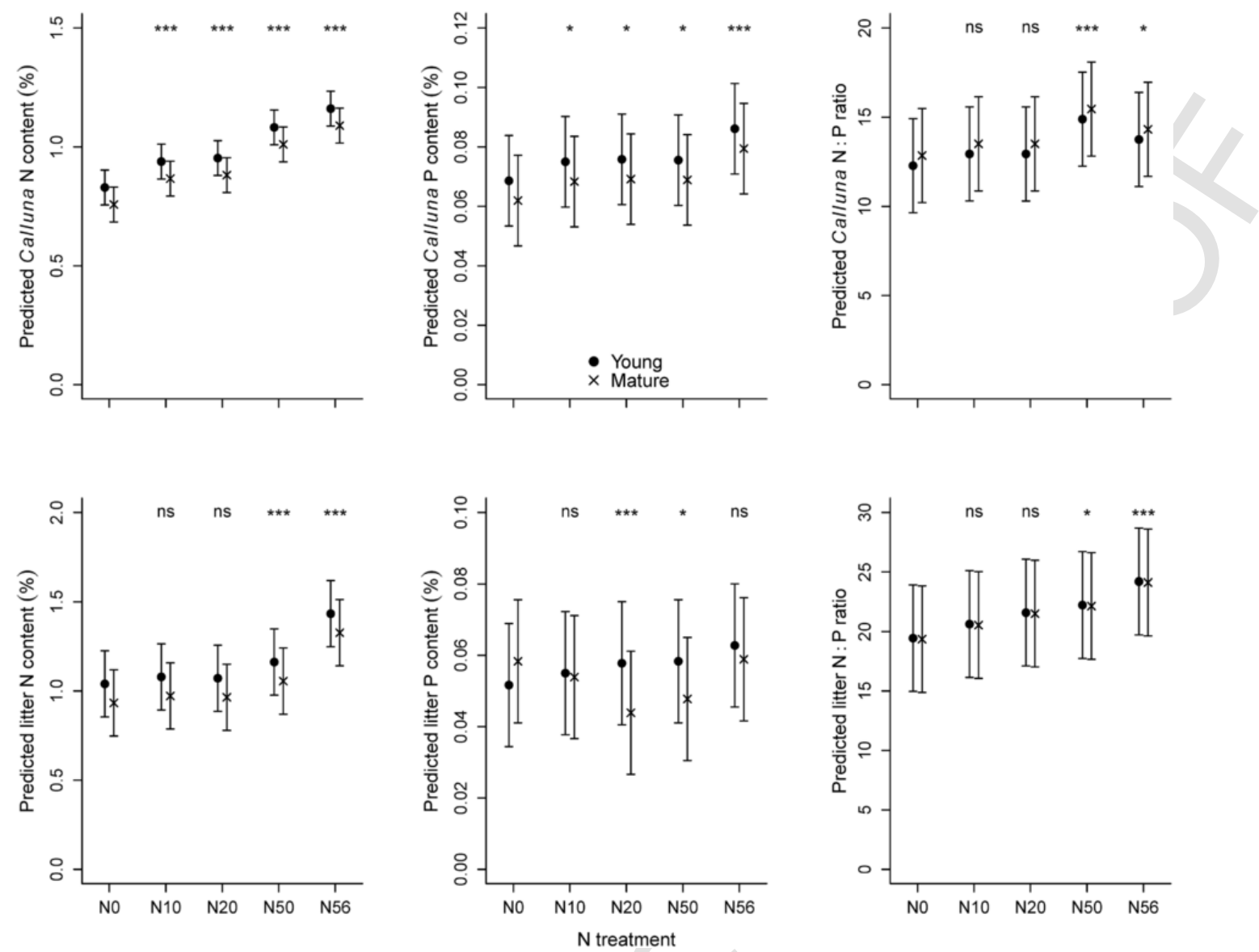

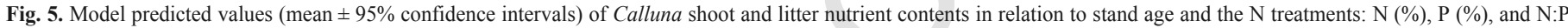

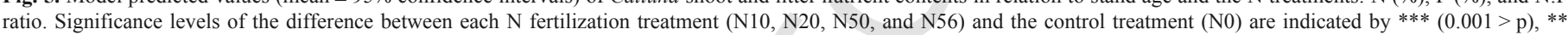
$(0.01>\mathrm{p}>0.001),{ }^{*}(0.05>\mathrm{p}>0.01)$, and $\mathrm{ns}(\mathrm{p}>0.05)$.

\subsection{Age-related effects of $N$ fertilization}

As expected, greater above-ground biomass in mature heathlands required higher $\mathrm{N}$ and $\mathrm{P}$ amounts to increase the relative nutrient contents of Calluna plants, and this effect was amplified by $\mathrm{N}$ fertilization. As a result, lower soil nutrient availability, mainly extractable $\mathrm{N}-\mathrm{NO}_{3}{ }^{-}$and available $\mathrm{P}$, was found in mature stands as compared to young ones. Furthermore, higher $\mathrm{N}$ demand by mature Calluna plants may have induced a lower $\mathrm{N}$ content in the soil microbial biomass as Calluna plants are better competitors than microbes for soil nutrients (Harrison et al., 2008). Similarly, higher P demand by mature Calluna plants may have induced a lower litter P content in the medium (N20), high (N50) and chronic high (N56) N treatments compared to young ones, likely due to $\mathrm{P}$ resorption from senescing plant biomass to physiologically-active shoots (Aerts and Chapin, 2000).

Mycorrhizal colonization of Calluna roots varied not only with plant age (Read and Pérez-Moreno, 2003), but also with the amount of experimental N-loading. Young Calluna plants in the control (N0), low (N10) and medium (N20) N treatments had significantly higher percentages of roots colonized by ericoid mycorrhizal fungi than mature plants (see Johansson, 1994), possibly to facilitate nutrient mobilization (Díaz et al., 2006; Read and Pérez-Moreno, 2003). However, mature Calluna plants subjected to the high (N50) and chronic high (N56) $\mathrm{N}$ treatments showed significantly greater mycorrhizal root colonization, probably in response to their higher $\mathrm{P}$ demands (Díaz et al., 2006; Johnson et al., 1999). Besides, higher aboveground biomass of mature stands could transfer greater amounts of photosynthesized-carbohydrates to ericoid mycorrhizal fungi for extending the mycelial network and increasing the access to soil nutrients (Johnson et al., 2005).

Finally, young Calluna plants had significantly higher shoot $\mathrm{N}$ and $\mathrm{P}$ and litter $\mathrm{N}$ contents than mature ones across all $\mathrm{N}$ treatments, very likely indicating that (1) young plants may acquire high amounts of nutrients to support their greater and faster annual growth rates (Gimingham, 1972; Jones and Power, 2015), while (2) mature plants with lower annual growth rates may store the acquired nutrients more evenly in their higher above- and below-ground plant biomass.

\subsection{Implications for ecosystem sustainability}

Our findings demonstrated that many components of the soil-microbial-enzyme system of marginal montane heathlands did not respond to the experimental addition of $\mathrm{N}$, even after long-term (10-year) high $\mathrm{N}$ loading ( $56 \mathrm{~kg} \mathrm{~N} \mathrm{ha}^{-1} \mathrm{yr}^{-1}$ plus background $\mathrm{N}$ deposition). This might suggest that montane heathland ecosystems may either be quite resistant and adapt well to enhanced $\mathrm{N}$ availability (Calvo et al., 2005; Marcos et al., 2003) or require longer time periods of $\mathrm{N}$ inputs before the deleterious effects of $\mathrm{N}$ loading on their biogeochemical properties become evident. It seems rather likely that the limited biotic activity and the slow nutrient cycling associated to the particular climatic conditions of montane heathlands may be 
Table 3

LMM results ['anova()' outputs] for the effects of heathland age (young vs mature) and $\mathrm{N}$ treatment (N0, N10, N20, N50, and N56) on Calluna shoot and litter nutrient contents. The interaction term (age $\times \mathrm{N}$ treatment) was retained in the models only when significant. Standard deviations (SD) and variance components (\%) of the random effects (identity of the heathland sites and the sampling years) are given. Df $=$ degrees of freedom. Significant p-values are in bold face.

\begin{tabular}{|c|c|c|c|c|c|c|c|}
\hline \multirow[t]{2}{*}{$\begin{array}{l}\text { Response } \\
\text { variable }\end{array}$} & \multicolumn{4}{|l|}{ Fixed effects } & \multicolumn{3}{|c|}{ Random effects } \\
\hline & $\begin{array}{l}\text { Predictor } \\
\text { variable }\end{array}$ & Df & $\begin{array}{l}\mathrm{F} \\
\text { value }\end{array}$ & $\mathrm{p}$ value & Variable & SD & Variance \\
\hline \multicolumn{8}{|c|}{ Calluna shoot nutrient contents } \\
\hline \multirow[t]{3}{*}{$\mathrm{N}$ content } & Age & 1 & 22.35 & $<0.001$ & Site & 0.023 & 13.96 \\
\hline & $\mathrm{N}$ treatment & 4 & 58.97 & $<0.001$ & Year & 0.041 & 24.56 \\
\hline & & & & & Residual & 0.102 & 61.48 \\
\hline \multirow[t]{3}{*}{ P content } & Age & 1 & 11.86 & $<0.001$ & Site & 0.011 & 39.98 \\
\hline & $\mathrm{N}$ treatment & 4 & 8.42 & $<0.001$ & Year & 0.004 & 14.62 \\
\hline & & & & & Residual & 0.013 & 45.40 \\
\hline \multirow[t]{3}{*}{$\mathrm{N}: \mathrm{P}$ ratio } & Age & 1 & 2.51 & 0.115 & Site & 2.033 & 40.53 \\
\hline & $\mathrm{N}$ treatment & 4 & 6.28 & $<0.001$ & Year & 0.582 & 11.61 \\
\hline & & & & & Residual & 2.400 & 47.86 \\
\hline \multicolumn{8}{|c|}{ Litter nutrient contents } \\
\hline \multirow[t]{3}{*}{$\mathrm{N}$ content } & Age & 1 & 21.50 & $<0.001$ & Site & 0.084 & 24.55 \\
\hline & $\mathrm{N}$ treatment & 4 & 39.12 & $<0.001$ & Year & 0.104 & 30.43 \\
\hline & & & & & Residual & 0.154 & 45.03 \\
\hline \multirow[t]{3}{*}{ P content } & Age & 1 & 5.96 & 0.016 & Site & 0.010 & 33.54 \\
\hline & $\mathrm{N}$ treatment & 4 & 3.18 & 0.015 & Year & 0.008 & 25.56 \\
\hline & $\begin{array}{l}\text { Age: } \mathrm{N} \\
\text { treatment }\end{array}$ & 4 & 3.75 & 0.006 & Residual & 0.013 & 40.90 \\
\hline \multirow[t]{3}{*}{$\mathrm{N}: \mathrm{P}$ ratio } & Age & 1 & 0.01 & 0.914 & Site & 3.002 & 30.60 \\
\hline & $\mathrm{N}$ treatment & 4 & 4.01 & 0.004 & Year & 1.460 & 14.88 \\
\hline & & & & & Residual & 5.348 & 54.52 \\
\hline
\end{tabular}

causative factors for this lack of response to the added $\mathrm{N}$ (Hagedorn et al., 2010). Furthermore, the apparent ability of montane Calluna plants to withstand disturbance factors (i.e., insect defoliation, drought and frost; see Section 2.2 'Experimental design'), suggests that these marginal heathlands may be quite resilient to $\mathrm{N}$ loading. Calvo et al. (2007) also found that the vegetation of Cantabrian montane heathlands is resilient to disturbances like $\mathrm{N}$ loading and intense management practices, recovering the pre-disturbed vegetation structure and composition. However, further long-term research is needed to fully understand the effects of chronic $\mathrm{N}$ deposition and its interactions with other episodic biotic and abiotic stressors (like insect pest outbreaks; Taboada et al., 2016) and global environmental change factors (Meyer-Grünefeldt et al., 2016) on the functioning of montane heathlands.

\section{Conclusions}

The results found in our study constitute a novelty in the field of heathland ecology in the context of accelerating global environmental change. This is the first assessment of the impact of cumulative $\mathrm{N}$ loading on the plant-soil-microbial-enzyme system of heathlands at their southern distribution limit, in relation to the life-history stage of the dominant dwarf shrub. Our results demonstrated for the first time that many biogeochemical properties of marginal montane heathlands (including soil organic $\mathrm{C}$ and total $\mathrm{N}$, extractable $\mathrm{N}_{-} \mathrm{NO}_{3}{ }^{-}$and available P; microbial biomass nutrient contents; and urease and $\beta$-glucosidase enzyme activities) do not respond to the enhanced availability of $\mathrm{N}$. However, $\mathrm{N}$ fertilization leads to increased soil extractable $\mathrm{N}-\mathrm{NH}_{4}{ }_{4}$, enhanced Calluna tissue $\mathrm{N}$ and $\mathrm{P}$ contents, increased litter $\mathrm{N}$ content, and enhanced shoot and litter N:P ratios; these effects being amplified under chronic (10-year) high $\mathrm{N}$ inputs $\left(56 \mathrm{~kg} \mathrm{~N}^{-1} \mathrm{yr}^{-1}\right.$ plus background $\mathrm{N}$ deposition). $\mathrm{N}$ enrichment further results in a greater P demand by Calluna plants, which is supplied by (1) an increase in acid phosphatase enzyme activity and by (2) higher percentages of root mycorrhizal colonization by ericoid fungi.

Furthermore, our study highlights the relevance of taking into account the age of vegetation when investigating the responses of the plant-soil-microbial-enzyme system of European heathlands to cumulative $\mathrm{N}$ loading. Calluna stands in the mature phase of development have lower soil extractable $\mathrm{N}-\mathrm{NO}_{3}{ }^{-}$and available $\mathrm{P}$, and lower plant tissue $\mathrm{N}$ and $\mathrm{P}$ contents and litter $\mathrm{N}$ content than young ones, owing to higher nutrient demands and uptake rates by mature Calluna plants with more above-ground biomass. These greater nutrient demands of mature Calluna plants possibly lead to (1) lower $\mathrm{N}$ content in the soil microbial biomass and (2) greater root mycorrhizal colonization by ericoid fungi under high $\mathrm{N}$ availability.

\section{Acknowledgements}

This work was supported by Consejería de Educación, Junta de Castilla y León (research projects LE021A08 and LE039A09) and Ministry of Science and Technology (research project CGL2006-10998-CO2-01/BOS). Calvo-Fernández was funded by the Spanish Ministry of Education (predoctoral fellowship FPU12/ 01494). We would like to thank David Johnson (Institute of Biological and Environmental Sciences, University of Aberdeen) for helping us with the analysis of mycorrhizal colonization. We are grateful for technical help provided by Rut Díez Romero (workplace ULE-15), supported by the European Social Fund and Youth Employment Initiative through the Regional Government of Castilla y León (Junta de Castilla y León). Finally, we thank the reviewers for their constructive comments.

\section{Appendix A. Supplementary data}

Supplementary data associated with this article can be found in the online version at http://dx.doi.org/10.1016/j.scitotenv.2017.08.307. These data include the Google map of the most important areas described in this article.

\section{References}

Aerts, R., Chapin, F.S., 2000. The mineral nutrition of wild plants revisited: a re-evaluation of processes and patterns. In: Fitter, A.H., Raffaelli, D.G. (Eds.), Advances in Ecological Research. vol. 30, Academic Press, London, pp. 1-67.

Ajwa, H.A., Dell, C.J., Rice, C.W., 1999. Changes in enzyme activities and microbial biomass of tallgrass prairie soil as related to burning and nitrogen fertilization. Soil Biol. Biochem. 31, 769-777.

Bähring, A., Fichtner, A., Ibe, K., Schütze, G., Temperton, V.M., von Oheimb, G., Härdtle, W., 2017. Ecosystem functions as indicators for heathland responses to nitrogen fertilisation. Ecol. Indic. 72, 185-193.

Bates, D., Maechler, M., Bolker, B., Walker, S., 2015. Fitting linear mixed-effects models using lme4. J. Stat. Softw. 67 (1), 1-48.

Bobbink, R., Hicks, W.K., Galloway, J.N., Spranger, T., Alkemade, R., Ashmore, M., Bustamante, M., Cinderby, S., Davidson, E., Dentener, F., Emmett, B., Erisman, J.W., Fenn, M., Gilliam, F., Nordin, A., Pardo, L., de Vries, W., 2010. Global assessment of nitrogen deposition effects on terrestrial plant diversity: a synthesis. Ecol. Appl. 20, 30-59.

Boot, C.M., Hall, E.K., Denef, K., Baron, J.S., 2016. Long-term reactive nitrogen loading alters soil carbon and microbial community properties in a subalpine forest ecosystem. Soil Biol. Biochem. 92, 211-220.

Bremner, J.M., 1965. Inorganic forms of nitrogen. In: Black, C.A., et al. (Eds.), Methods of Soil Analysis: Part 2. Agronomy. 9, American Society of Agronomy, Madison, WI, pp. 1179-1237.

Bremner, J.M., Mulvaney, C.S., 1982. Nitrogen total. In: Page, A.L., Miller, E.M., Keeney, D.R. (Eds.), Methods of Soil Analysis: Part 2, Chemical and Microbiological Properties. American Society of Agronomy, Madison, WI, pp. 595-624.

Britton, A.J., Helliwell, R.C., Fisher, J.M., Gibbs, S., 2008. Interactive effects of nitrogen deposition and fire on plant and soil chemistry in an alpine heathland. Environ. Pollut. 156, 409-416. 
Brookes, P.C., Landman, A., Pruden, G., Jenkinson, D.S., 1985. Chloroform fumigation and the release of soil nitrogen: a rapid direct extraction method to measure microbial biomass nitrogen in soil. Soil Biol. Biochem. 17 (6), 837-842.

Cairney, J.W.G., Burke, R.M., 1998. Extracellular enzyme activities of the ericoid mycorrhizal endophyte Hymenoscyphus ericae (Read) Korf \& Kernan: their likely roles in decomposition of dead plant tissue in soil. Plant Soil 205, 181-192.

Calvo, L., Alonso, I., Fernández, A.J., De Luis, E., 2005. Short-term study of effects of fertilisation and cutting treatments on the vegetation dynamics of mountain heathlands in Spain. Plant Ecol. 179, 181-191.

Calvo, L., Alonso, I., Marcos, E., De Luis, E., 2007. Effects of cutting and nitrogen deposition on biodiversity in Cantabrian heathlands. Appl. Veg. Sci. 10, 43-52.

Calvo-Fernández, J., Marcos, E., Calvo, L., Härdtle, W., 2015. Allocation patterns of airborne nitrogen in mountainous heathlands-a ${ }^{15} \mathrm{~N}$ tracer study in the Cantabrian Mountains (NW Spain). Ecol. Eng. 84, 128-135.

Calvo-Fernández, J., Marcos, E., Calvo, L., 2017. Bulk deposition of atmospheric inorganic nitrogen in mountainous heathland ecosystems in North-Western Spain. Atmos. Res. 183, 237-244.

Camenzind, T., Homeier, J., Dietrich, K., Hempel, S., Hertel, D., Krohn, A. Leuschner, C., Oelmann, Y., Olsson, P.A., Suárez, J.P., Rilling, M.C., 2016. Opposing effects of nitrogen versus phosphorus additions on mycorrhizal fungal abundance along an elevational gradient in tropical montane forests. Soil Biol Biochem. 94, 37-47.

Caporn, S.J.M., Song, W., Read, D.J., Lee, J.A., 1995. The effect of repeated nitrogen fertilization on mycorrhizal infection in heather [Calluna vulgaris (L.) Hull]. New Phytol. 129, 605-609.

Cenini, V.L., Fornara, D.A., McMullan, G., Ternan, N., Carolan, R., Crawley, M.J., Clément, J.-C., Lavorel, S., 2016. Linkages between extracellular enzyme activities and the carbon and nitrogen content of grassland soils. Soil Biol. Biochem. 96, 198-206.

Contosta, A.R., Frey, S.D., Cooper, A.B., 2015. Soil microbial communities vary as much over time as with chronic warming and nitrogen additions. Soil Biol. Biochem. 88, 19-24.

R Core Team, 2016. R: A Language and Environment for Statistical Computing. R Foundation for Statistical Computing, Vienna, Austria, Available at https://www. R-project.org/.

Cuesta, D., Taboada, A., Calvo, L., Salgado, J.M., 2008. Short-term effects of experimental fertilization on arthropods associated with Calluna vulgaris heathlands in North-West Spain. Environ. Pollut. 152, 394-402.

De Vries, W., Solberg, S., Dobbertin, M., Sterba, H., Laubhann, D., van Oijen, M., Evans, C., Gundersen, P., Kros, J., Wamelink, G.W.W., Reinds, G.J., Sutton, M.A., 2009. The impact of nitrogen deposition on carbon sequestration by European forests and heathlands. For. Ecol. Manag. 258, 1814-1823.

Díaz, A., Green, I., Benvenuto, M., Tibbett, M., 2006. Are ericoid mycorrhizas a factor in the success of Calluna vulgaris heathland restoration?. Restor. Ecol. 14 (2), $187-195$.

Du, Y.H., Guo, P., Liu, J., Wang, C., Yang, N., Jiao, Z., 2014. Different types of nitrogen deposition show variable effects on the soil carbon cycle process of temperate forests. Glob. Chang. Biol. 20, 3222-3228.

Erisman, J.W., Galloway, J., Seitzinger, S., Bleeker, A., Butterbach-Bahl, K., 2011. Reactive nitrogen in the environment and its effect on climate change. Curr. Opin. Environ. Sustain. 3, 281-290.

European Commission, 2005. Soil Atlas of Europe. European Soil Bureau Network, European Commission. Office for Official Publications of the European Communities, L-2995 Luxembourg, (128 pp.).

Fagúndez, J., 2013. Heathlands confronting global change: drivers of biodiversity loss from past to future scenarios. Ann. Bot. 111, 151-172.

Fatemi, F.R., Fernandez, I.J., Simon, K.S., Dail, D.B., 2016. Nitrogen and phosphorus regulation of soil enzyme activities in acid forest soils. Soil Biol. Biochem. 98, 171-179.

Friedrich, U., von Oheimb, G., Dziedek, C., Kriebitzsch, W.-U., Selbmann, K., Härdtle, W., 2011. Mechanisms of purple moor-grass (Molinia caerulea) encroachmen in dry heathland ecosystems with chronic nitrogen inputs. Environ. Pollut. 159, $3553-3559$

Galloway, J.N., Dentener, F.J., Capone, D.G., Boyer, E.W., Howarth, R.W., Seitzinger, S.P., Asner, G.P., Cleveland, C.C., Green, P.A., Holland, E.A., Karl, D.M., Michaels, A.F., Porter, J.H., Townsend, A.R., Vörösmarty, C.J., 2004. Nitrogen cycles: past, present, and future. Biogeochemistry 70, 153-226.

Gao, Y., He, N., Zhang, X., 2014. Effects of reactive nitrogen deposition on terrestrial and aquatic ecosystems. Ecol. Eng. 70, 312-318.

García-Gómez, H., Garrido, J.L., Vivanco, M.G., Lassaletta, L., Rábago, I., Àvila, A., Tsyro, S., Sánchez, G., González Ortiz, A., González-Fernández, I., Alonso, R., 2014. Nitrogen deposition in Spain: modelled patterns and threatened habitats within the Natura 2000 network. Sci. Total Environ. 485-486, 450-460.

Gimingham, C.H., 1972. Ecology of Heathlands. Chapman and Hall, London, UK.

Güsewell, S., 2004. N:P ratios in terrestrial plants: variation and functional significance. New Phytol. 164, 243-266.
Hagedorn, F., Mulder, J., Jandl, R., 2010. Mountain soils under a changing climate and land-use. Biogeochemistry 97, 1-5

Hall, J., Curtis, C., Dore, T., Smith, R., 2015. Methods for the Calculation of Critical Loads and Their Exceedances in the UK. NERC/Centre for Ecology \& Hydrology, Bangor, UK, (108 pp.).

Härdtle, W., Niemeyer, M., Niemeyer, T., Assmann, T., Fottner, S., 2006. Can management compensate for atmospheric nutrient deposition in heathland ecosystems?. J. Appl. Ecol. 43, 759-769.

Härdtle, W., von Oheimb, G., Gerke, A.-K., Niemeyer, M., Niemeyer, T., Assmann, T., Drees, C., Matern, A., Meyer, H., 2009. Shifts in N and P budgets of heathland ecosystems: effects of management and atmospheric inputs. Ecosystems 12, 298-310.

Harrison, K.A., Bol, R., Bardgett, R.D., 2008. Do plant species with different growth strategies vary in their ability to compete with soil microbes for chemical forms of nitrogen?. Soil Biol. Biochem. 40, 228-237.

Haugwitz, M.S., Michelsen, A., Schmidt, I.K., 2011. Long-term microbial control of nutrient availability and plant biomass in a subartic-alpine heath after addition of carbon, fertilizer and fungicide. Soil Biol. Biochem. 43, 179-187.

Henning, K., von Oheimb, G., Härdtle, W., Fichtner, A., Tischew, S., 2017. The reproductive potential and importance of key management aspects for successful Calluna vulgaris rejuvenation on abandoned continental heaths. Ecol. Evol. 1-10.

Jian, S., Li, J., Chen, J., Wang, G., Mayes, M.A., Dzantor, K.E., Hui, D., Luo, Y., 2016. Soil extracellular enzyme activities, soil carbon and nitrogen storage under nitrogen fertilization: a meta-analysis. Soil Biol. Biochem. 101, 32-43.

Johansson, M., 1994. Quantification of mycorrhizal infection in roots of Calluna vulgaris (L.) Hull from Danish heathland. Soil Biol. Biochem. 26, 763-766.

Johnson, D., Leake, J.R., Lee, J.A., Campbell, C.D., 1998. Changes in soil microbial biomass and microbial activities in response to 7 years simulated pollutant nitrogen deposition on a heathland and two grasslands. Environ. Pollut. 103, 239-250.

Johnson, D., Leake, J.R., Lee, J.A., 1999. The effects of quantity and duration of simulated pollutant nitrogen deposition on root-surface phosphatase activities in calcareous and acid grasslands: a bioassay approach. New Phytol. 141, 433-442.

Johnson, D., Ijdo, M., Genney, D.R., Anderson, I.C., Alexander, I.J., 2005. How do plants regulate the function, community structure, and diversity of mycorrhizal fungi?. J. Exp. Bot. 56 (417), 1751-1760.

Jones, A.G., Power, S.A., 2012. Field-scale evaluation of effects of nitrogen deposition on the functioning of heathland ecosystems. J. Ecol. 100, 331-342.

Jones, A.G., Power, S.A., 2015. Functional relationships with N deposition differ according to stand maturity in Calluna-dominated heathland. Ambio 44, 131-141.

Kalra, Y.P., Maynard, D.G., 1991. Methods manual for forest soil and plant analysis In: Informatoin Report NOR-X-319. Northern Forestry Centre, Alberta, Canada.

Kandeler, E., Gerber, H., 1988. Short-term assay of soil urease activity using colorimetric determination of ammonium. Biol. Fertil. Soils 6, 68-72.

Keeney, D.R., Nelson, D.W., 1982. Nitrogen in organic forms. In: Page, A.L., Miller, R.H., Keeney, D.R. (Eds.), Methods of Soil Analysis, Part 2, Chemical and Microbiological Properties. American Society of Agronomy, Madison, WI, pp. 643-698.

Kooijman, A.M., Dopheide, J.C.R., Sevink, J., Takken, I., Verstraten, J.M., 1998. Nutrient limitations and their implications on the effects of atmospheric deposition in coastal dunes; lime-poor and lime-rich sites in the Netherlands. J. Ecol. 86 (3), 511-526.

Kuznetsova, A., Brockhoff, P.B., Christensen, R.H.B., 2016. lmerTest: Tests in Linear Mixed Effects Models. Available at https://CRAN.R-project.org/ package $=$ lmerTestR package version 2.0-32.

López-Poma, R., Bautista, S., 2014. Plant regeneration functional groups modulate the response to fire of soil enzyme activities in a Mediterranean shrubland. Soil Biol. Biochem. 79, 5-13.

Marcos, E., Calvo, L., Luis-Calabuig, E., 2003. Effects of fertilization and cutting on the chemical composition of vegetation and soils of mountain heathlands in Spain. J. Veg. Sci. 14, 417-424.

Marcos, E., Villalón, C., Calvo, L., Luis-Calabuig, E., 2009. Short-term effects of experimental burning on soil nutrients in the Cantabrian heathlands. Ecol. Eng. 35, $820-828$.

McGonigle, T.P., Miller, M.H., Evans, D.G., Fairchild, G.L., Swan, J.A., 1990. A new method which gives and objective measure of colonization of roots by vesicular-arbuscular mycorrhizal fungi. New Phytol. 115, 495-501.

Meyer-Grünefeldt, M., Calvo, L., Marcos, E., von Oheimb, G., Härdtle, W., 2015. Impacts of drought and nitrogen addition on Calluna heathlands differ with plant life-history stage. J. Ecol. 103, 1141-1152.

Meyer-Grünefeldt, M., Belz, K., Calvo, L., Marcos, E., von Oheimb, G., Härdtle, W., 2016. Marginal Calluna populations are more resistant to climate change, but not under high-nitrogen loads. Plant Ecol. 217, 111-122.

Ministerio de Agricultura, Pesca y Alimentación, 1986. Métodos Oficiales de Análisis. Tomo III. Secretaria General técnica. Direccción General de Política Alimentaria, M.A.P.A., Madrid, (In Spanish).

Nielsen, P.L., Andresen, L.C., Michelsen, A., Schmidt, I.K., Kongstad, J., 2009. Seasonal variations and effects of nutrient applications on $\mathrm{N}$ and $\mathrm{P}$ and microbial biomass under two temperate heathland plants. Appl. Soil Ecol. 42, 279-287. 
Ochoa-Hueso, R., Allen, E.B., Branquinho, C., Cruz, C., Dias, T., Fenn, M.E., Manrique, E., Pérez-Corona, M.E., Sheppard, L., Stock, W.D., 2011. Nitrogen deposition effects on Mediterranean-type ecosystems: an ecological assessment. Environ. Pollut. 159, 2265-2279.

Ochoa-Hueso, R., Stevens, C.J., Ortiz-Llorente, M.J., Manrique, E., 2013. Soil chemistry and fertility alterations in response to $\mathrm{N}$ application in a semiarid Mediterranean shrubland. Sci. Total Environ. 452-453, 78-86.

Ochoa-Hueso, R., Bell, M.D., Manrique, E., 2014. Impacts of increased nitrogen deposition and altered precipitation regimes on soil fertility and functioning in semiarid Mediterranean shrublands. J. Arid Environ. 104, 106-115.

von Oheimb, G., Power, S.A., Falk, K., Friedrich, U., Mohamed, A., Krug, A., Boschatzke, N., Härdtle, W., 2010. N:P ratio and the nature of nutrient limitation in Calluna-dominated heathlands. Ecosystems 13, 317-327.

Papanikolaou, N., Britton, A.J., Helliwell, R.C., Johnson, D., 2010. Nitrogen deposition vegetation burning and climate warming act independently on microbial community structure and enzyme activity associated with decomposing litter in low-alpine heath. Glob. Chang. Biol. 16, 3120-3132.

Phoenix, G.K., Booth, R.E., Leake, J.R., Read, D.J., Grime, J.P., Lee, J.A., 2003. Simulated pollutant nitrogen deposition increases $\mathrm{P}$ demand and enhances root-surface phosphatase activities of three plant functional types in calcareous grassland. New Phytol. 161, 279-289.

Phoenix, G.K., Emmett, B.A., Britton, A.J., Caporn, S.J.M., Dise, N.B., Helliwell, R., Jones, L., Leake, J.R., Leith, I.D., Sheppard, L.J., Sowerby, A., Pilkington, M.G., Rowe, E.C., Ashmore, M.R., Power, S.A., 2012. Impacts of atmospheric nitrogen deposition: responses of multiple plant and soil parameters across contrasting ecosystems in long-term field experiments. Glob. Chang. Biol. 18, 1197-1215.

Pilkington, M.G., Caporn, S.J.M., Carroll, J.A., Cresswell, N., Lee, J.A., Emmett, B.A., Johnson, D., 2005. Effects of increased deposition of atmospheric nitrogen on an upland Calluna moor: N and P transformations. Environ. Pollut. 135, 469-480.

Pilkington, M.G., Caporn, S.J.M., Carroll, J.A., Cresswell, N., Lee, J.A., Reynolds, B., Emmett, B.A., 2005. Effects of increased deposition of atmospheric nitrogen on an upland moor: nitrogen budgets and nutrient accumulation. Environ. Pollut. 138, 473-484.

Power, S.A., Green, E.R., Barker, C.G., Bell, N.B., Ashmore, M.R., 2006. Ecosystem recovery: heathland response to a reduction in nitrogen deposition. Glob. Chang. Biol. 12, 1241-1252.

Ramírez, K.S., Craine, J.M., Fierer, N., 2012. Consistent effects of nitrogen amendments on soil microbial communities and processes across biomes. Glob. Chang. Biol. 18, 1918-1927.

Read, D.J., Pérez-Moreno, J., 2003. Mycorrhizas and nutrient cycling in ecosystems - a journey towards relevance?. New Phytol. 157, 475-492.

Rinnan, R., Michelsen, A., Bååth, E., Jonasson, S., 2007. Fifteen years of climate change manipulations alter soil microbial communities in a subarctic heath ecosys tem. Glob. Chang. Biol. 13, 28-39.

Rivero Fernández, C., Rabago Juan-Aracil, I., Sousa Carrera, M., Lorente Ibáñez, M., Schmid, T., 1996. Cálculo y cartografía de cargas críticas para España. Aplicación del model SMB. CIEMAT, Madrid.

Rowe, E.C., Smart, S.M., Kennedy, V.H., Emmett, B.A., Evans, C.D., 2008. Nitrogen deposition increases the acquisition of phosphorus and potassium by heather Calluna vulgaris. Environ. Pollut. 155, 201-207.
Sala, O.E., Stuart Chapin III, F., Armesto, J.J., Berlow, E., Bloomfield, J., Dirzo, R., Huber-Sanwald, E., Huenneke, L.F., Jackson, R.B., Kinzig, A., Leemans, R., Lodge, D.M., Mooney, H.A., Oesterheld, M., LeRoy Poff, N., Sykes, M.T., Walker, B.H., Walker, M., Wall, D.H., 2000. Global biodiversity scenarios for the year 2100. Science 287, 1770-1774.

Sinsabaugh, R.L., Follstad, J.J., 2012. Ecoenzymatic stoichiometry and ecological theory. Annu. Rev. Ecol. Evol. Syst. 43, 313-343

Song, Y., Song, C., Meng, H., Swarzenski, C.M., Wang, X., Tan, W., 2017. Nitrogen additions affect litter quality and soil biochemical properties in a peatland of Northeast China. Ecol. Eng. 100, 175-185.

Southon, G.E., Green, E.R., Jones, A.G., Barker, C.G., Power, S.A., 2012. Long-term nitrogen additions increase likelihood of climate stress and affect recovery from wildfire in a lowland heath. Glob. Chang. Biol. 18, 2824-2837.

Southon, G.E., Field, C., Caporn, S.J.M., Britton, A.J., Power, S.A., 2013. Nitrogen deposition reduces plant diversity and alters ecosystem functioning: field-scale evidence from nationwide survey of UK heathlands. PLoS One 8 (4), e59031.

Stevens, C.J., Manning, P., van den Berg, L.J.L., de Graaf, M.C.C., WiegerWamelink, G.W., Boxman, A.W., Bleeker, A., Vergeer, P., Arroniz-Crespo, M., Limpens, J., Lamers, L.P.M., Bobbink, R., Dorland, E., 2011. Ecosystem responses to reduced and oxidized nitrogen inputs in European terrestrial habitats. Environ. Pollut. 159, $665-676$.

Tabatabai, M.A., 1982. Soil enzymes. In: Page, A.L., Miller, E.M., Keeney, D.R. (Eds.), Methods of Soil Analyses, Part 2, Chemical and Microbiological Properties. American Society of Agronomy, Madison, WI, pp. 903-947.

Tabatabai, M.A., Bremner, J.M., 1969. Use of p-nitrophenyl phosphate for assay of soil phosphatase activity. Soil Biol. Biochem. 1, 301-307.

Taboada, A., Marcos, E., Calvo, L., 2016. Disruption of trophic interactions involving the heather beetle by atmospheric nitrogen deposition. Environ. Pollut. 218, 436-445.

Vance, E.D., Brookes, P.C., Jenkinson, D.S., 1987. An extraction method for measuring soil microbial biomass C. Soil Biol. Biochem. 19, 703-707.

Vet, R., Artz, R.S., Carou, S., Shaw, M., Ro, C.-U., Aas, W., Baker, A., Bowersox, V.C., Dentener, F., Galy-Lacaux, C., Hou, A., Pienaar, J.J., Gillet, R., Forti, M.C., Gromov, S., Hara, H., Khodzher, T., Mahowald, N.M., Nickovic, S., Rao, P.S.P., Reid, N.W., 2014. A global assessment of precipitation chemistry and deposition of sulfur, nitrogen, sea salt, base cations, organic acids, acidity and $\mathrm{pH}$, and phosphorus. Atmos. Environ. 93, 3-100.

Vierheilig, H., Coughlan, A.P., Wyss, U., Piché, Y., 1998. Ink and vinegar, a simple staining technique for arbuscular-mycorrhizal fungi. Appl. Environ. Microbiol. 64 (12), 5004-5007.

Wendling, M., Büchi, L., Amossé, C., Sinaj, S., Walter, A., Charles, R., 2016. Influence of root and leaf traits on the uptake of nutrient in cover crops. Plant Soil 409 (1), 419-434.

Yesmin, L., Gammack, S.M., Cresser, M.S., 1996. Effects of atmospheric N deposition on ericoid mycorrhizal infection of Calluna vulgaris growing in peat soils. Appl. Soil Ecol. 4, 49-60.

Zhu, X., Zhang, W., Chen, H., Mo, J., 2015. Impacts of nitrogen deposition on soil nitrogen cycle in forest ecosystems: a review. Acta Ecol. Sin. 35, 35-43. 